\title{
Effects of Addition of Sprouted Decorticated Roselle Seeds Flour on Rheological Properties
}

\author{
Karma Bako Rimamcwe, U. D. Chavan* and P. M. Kotecha \\ Department of Food Science and Technology, Mahatma Phule Krishi Vidyapeeth, \\ Rahuri, India \\ *Corresponding author
}

\section{A B S T R A C T}

Keywords

Sprouted

Decorticated

Roselle seed flour,

Rheology,

Amylograph,

Farinograph and

Extensograph

Article Info

Accepted:

17 September 2020

Available Online:

10 October 2020
The present study was undertaken with the objectives to study the effect of addition of sprouted decorticated Roselle seed flour with wheat flour on rheological properties for bakery products. For this study the Roselle seed were procured from the local market and then soaking, sprouting/germination and decortications treatments were given to the seeds. All experiments were laid in completely randomized design with suitable replications for statistical analysis. The pre-treatments soaking, sprouting, decortications, and whole seed were adopted in this investigation to ascertain the best treatment for onward inclusion in bakery products. Amylograph, farinograph and extensograph properties of the pretreatments were also studied. The preliminary investigations adjudged sprouted decorticated Roselle seed flour (SDRSF) have superior nutritional and functional qualities. The decorticated Roselle seed flour had higher nutrient contents than the whole seeds. Therefore, this treatment was used to study the amylograph, farinograph and extensograph properties of the composite flour. These properties showed good characteristics for using this flour in bakery products.

\section{Introduction}

Roselle (Hibiscus sabdariffa Linn.) is a tropical plant belonging to the Family Malvaceae and widely cultivated for its jute like fiber in India, the East Indies, Nigeria and to some extent in tropical America (Yayock, 1988). A woody sub-shrub growing 7-8 feet $(2-2.5 \mathrm{~m})$ tall, acting as annual or perennial, takes about six months to mature. The mature plants are highly drought resistant but may require water during dry periods when soil moisture is depleted to the point where wilting occurs. Roselle requires a chalky, loamy and peat-rich soil with $\mathrm{pH}$ of 7.6-9.0; and grows best in weakly alkaline soil (Myfolia, 2016).

The seeds of this crops from which edible oil could be extracted are being wasted in its production area after the farmers might have 
taken the quantity needed for the next planting season for the calyces production (Bamigboy et al., 2009; Emmy Hainida et al., 2008). The seeds have been found to be a source of highly valued vegetable oil with properties similar to that of crude olive. In terms of their oil content, the seeds of $H$. sabdariffa are richer in lipids (22\%) than most well-known seed oil such as those derived from Cotton (13\%), Soybean (14\%) and Palm fruit (20\%) (Nzikou et al., 2012; Karma and Chavan, 2016; Karma et al., 2017a, b, c, d; Karma et al., 2018a, b, c; Karma et al., 2020).

Nutritionally important antioxidants such as tocopherols improve the stability of oil. In a study, Roselle seed oil (RSO) and Roselle seed extract (RSE) was mixed with Sunflower oil, respectively to monitor degradation rate and investigate antioxidant activity during accelerated storage. The antioxidant activity was found to stabilize Sunflower oil of various samples and in the order of RSE > RSO > Tocopherol > Sunflower oil (Nyam et al., 2012).

Roselle seed oil are richer in carotenoids than expensive oils like niger (Guizotia abyssinica) seed oil (70.2 $\pm 0.03 \mathrm{mg} \beta$-carotene $/ 100 \mathrm{~g})$ and coriander (Coriander sativum) seed oil (89.2 $\pm 0.05 \mathrm{mg} \quad \beta$-carotene/100g) (Ramadan and Morsel, 2004). Carotenoids are important ingredients in cosmetic industries due to their antioxidant activity and protective effect on the skin (Platon, 1997). Therefore, Roselle seeds oil has good potential for utilization in the Cosmetic Industry.

The proximate composition of whole Roselle seeds indicated that, seeds contained relatively high fat and protein (as $\% N x 6.25$; $20.97 \%$ and $29.61 \%$ respectively). The physico-chemical parameters of crude oil extracted from Roselle seeds by soaking at room temperature (cold extraction) indicated the oils had 1.4674 refractive index; 0.078 (at 420nm) yellow-greenish colour, $0.78 \%$ acidity, 198.82 saponification value, 97.62 (g of $\mathrm{I}_{2} / 100 \mathrm{~g}$ oil) iodine value; $1.52 \%$ unsaponifiable matter; 4.82 (Meq $0_{2} / \mathrm{Kg}$ oil) peroxide value; $6.21 \mathrm{p}$-anisidine value; and 15.85 totox number. Gas Liquid Chromatography technique has been developed for identification and quantitative determination of total unsaturated and saturated fatty acids. This technology showed that Roselle crude oil had $73.40 \%$ unsaturated and $26.57 \%$ saturated fatty acids respectively. Major fatty acid found was oleic acid $(38.46 \%)$ followed by linoleic $(33.25 \%)$ and Stearic $(5.79 \%)$. Stability of crude Roselle seed oil against oxidation during the accelerated storage of oil indicated that the crude oil induction period to be 10 days at $65^{\circ} \mathrm{C}$. The relatively high fat content of the seeds and high protein content of resulted meal beside the relatively high oxidation stability of Roselle suggest that Roselle seeds could be a novel and economic source of healthy edible fat and for other food industry applications.

Protein fractions, proteins isolates or concentrates obtained from Roselle seeds might be an alternative source of low cost protein substitute in dietary supplement in ingredients for food industry. This may reduce the heavy dependence on conventional sources such as animal, fish and soybean proteins. At present, there are very few reports on harnessing the bio-nutritional potential of Roselle seeds in value added products (Nyam et al., 2014). Adding cereals with complementary nutritive profiles, such as Roselle seeds, may yield a more complete enrich food source (Okafor et al., 2002; Arshad et al., 2007; Bala et al., 2015; Wani et $a l ., 2015)$. Hence, the aim of this study was to investigate the Rheological properties of Roselle seed flour for utilization in various food products. 


\section{Materials and Methods}

\section{Raw materials collection}

Roselle (Hibiscus sabdariffa Linn.) and Wheat (Triticum aestivum spp.) seeds were both sourced from local vegetable markets in Ahmednagar, Maharashtra State, India and both were of local varieties.

\section{Cleaning}

The seeds were cleaned by washing to separate poor quality seeds, adhering dust particles, stones, plant debris and were dried carefully at ambient conditions to preserve its nutritive value, packed in a HDPE bag and stored in a cool dry place until used.

\section{Germination and Decortication}

The cleaned seeds were soaked for 6 hours to activate the process of germination, after which the seeds were washed and allowed to drain. The drained seeds were then spread on a damped cloth in a perforated container with water sprinkled occasionally in a dark room to activate germination for a 12 hour period; then the seed was pressed between hand fingers to neatly separate out the bran (seed coat) from the cotyledons. The bran and cotyledons were dried at $105^{\circ} \mathrm{C}$ for $3 \mathrm{hrs}$ in an oven. The dry weight was then obtained using Sartorius AG Germany (Model: CPA323SOCE) digital weighing balance of $0.001 \mathrm{~g}$ accuracy and the percentage was calculated and recorded and cotyledons grinded to 60 mesh, packed in a HDPE bag and stored in a cool dry place until used.

\section{Methods}

At every stage of the experiments, standard methods were adopted and the impact assessment on reproducibility a do-it-yourself approach was considered to allow the whole process to be reproduced by anyone achieving the same results within the acceptable limits of errors.

\section{Experimental design}

Based on review of literature and preliminary studies, the experimental work plan was prepared and experimental parameters were identified. The detailed work plan, treatments variables and experimental design are clearly outlined below: The results obtained were statistically analyzed by C.R.D. (Completely Randomized Design) as given by Panse and Sukhatme (1967).

\section{Rheological study}

A comparative rheological analysis on the effects of incorporating sprouted decorticated Roselle seeds flour in composite formulation with wheat was evaluated using Amylograph, Farinograph and Extensograph, determined according to AACC approved methods No. 22-10, 54-21 and 54-10 respectively (A.A.C.C., 2000).

\section{Amylograph}

Amylograph was used to measure the gelatinization temperature of the Roselle seed and wheat composite flour slurry. In amylograph, a rotating suspension of slurry (sample composite flour mixed with distilled water) was heated with a constant heating rate of $1.5^{\circ} \mathrm{C} / \mathrm{min}$ within a rotating bowl. Depending on the viscosity of the suspension, a measuring sensor reaching into the bowl was deflected. This deflection was measured as viscosity over time vs. temperature and recorded on-line. The overall test time is $42 \mathrm{~min}+5 \mathrm{~min}$ holding time $=47 \mathrm{~min}$.

\section{Method}

The software adjusted sample weight and volume, $\mathrm{ml}$, distilled water based on sample moisture were mixed to make slurry. The 
slurry was stirred while being heated in the amylograph, beginning at $30^{\circ} \mathrm{C}$ and increasing at a constant rate of $1.5^{\circ} \mathrm{C}$ per minute until the slurry reaches $95^{\circ} \mathrm{C}$. The amylograph records the resistance to stirring as a viscosity curve on graph paper.

\section{Farinograph}

The farinograph was used to study the water absorption and dough development properties of the Roselle seed and wheat composite flour. The Farinograph consists of a drive unit with continuous speed control and an attached measuring mixer for mixing the dough to be tested. Flour/water suspension in the heated measuring mixer is subjected to a defined mechanical stress by the rotating mixer blades. The resistance of the dough against the blades, which depends on the dough viscosity, is measured as torque, recorded and plotted online as a function of time in a clear color diagram recording values of water absorption, dough development time, dough stability, degree of softening, consistency and farinograph quality number.

\section{Method}

The adjusted flour sample weights based on sample moisture content were weighed and placed into the corresponding farinograph mixing bowl. Also the calculated amount of distilled water from the systems software from a burette was added to the flour in the mixing bowl and mixed to form dough; as the dough is mixed, the farinograph records a curve on graph paper. By adding appropriate amount of water the curve is centered on the 500-brabender unit (BU) line $\pm 20 \mathrm{BU}$ and it was ran until the curve leaves the 500-BU line.

\section{Extensograph}

The extensograph was used to study the strechability of the Roselle seed and wheat composite flour dough samples. The extensograms shown by extensograph recorded online and represented as a colour diagram on the monitor showed the exerted force as a function of the stretching length (time). The shape of the measuring curve and its variation during the individual proving times, the area below the curve as well as the numerical values of the different evaluation points, permit to make reliable and reproducible statements as to the flour quality and the suitability of the flour for baking. Furthermore, the influence of flour additives on the flour characteristics can be made evident.

\section{Method}

The adjusted farinograph system software sample flour weight based on sample moisture contents before test was combined with a salt solution and mixed in the farinograph to form dough. After the dough was rested for $5 \mathrm{~min}$, it is mixed to maximum consistency (peak time). The $150 \mathrm{~g}$ sample of prepared dough was placed on the extensograph rounder and shaped into a ball. The ball of dough was removed from the rounder and shaped into a cylinder. The dough cylinder was placed into the extensograph dough cradle, secured with pins, and rested at interval of 30,60 and 90 minutes respectively in a controlled environment adjusted at $30^{\circ} \mathrm{C}$ using automated steam bath. After each respective minute a hook was drawn through the dough, stretching it downwards until it breaks. The extensograph was recorded as a curve on graph paper as the test was run.

\section{Results and Discussion}

\section{Rheological studies}

An in-depth literature search revealed that the rheological effects of incorporating Roselle seed flour in a dough composite formulation 
with wheat flour have not yet been studied. Thus this study was conducted to investigate the rheological behaviour of the composite flour to ascertain the baking properties and potentials of the flour mixtures. The results for the Amylograph, Farinograph and Extensograph are outlined below:

\section{Amylograph studies}

The gelatinization and pasting characteristics of the composite flours (sprouted decorticated Roselle seed flour and wheat flour) were studied. The results outlined showed that the baking properties of flour are based not only on the gluten characteristics but also to a great degree on the extent of gelatinization of the starch. The porosity and the crumb structure of the baked goods depend upon this factor which also determines the degree of firmness and the shelf life of the product (AACC, 2000 standard method 22-10).

The results of amylograph of composite flour (sprouted decorticated Roselle seed flour and wheat flour) are presented in Table 1 for the characteristics: beginning of gelatinization, gelatinization temperature and gelatinization maximum. The results showed that the higher percentage of sprouted decorticated Roselle seed flour (SDRSF) inclusion in the composite mix the greater increased temperature required beginning gelatinization of the composite slurry in all the treatments, with a corresponding decrease in gelatinization temperature showing an inverse relationship. The difference in gelatinization temperatures between each of the treatment were considered significant at $\mathrm{P}<0.05$; but $10 \%$ and $15 \%$ substitution were at par with control. The difference in beginning of gelatinization and gelatinization temperature of the slurry decreases with inclusion of SDRSF which reflects the degree and the extent of gelatinization. Ten (10) percent Roselle seed inclusion showed a higher deviation followed by $15 \%$ with $25 \%$ having the least value. There was a significant difference in the temperature $(\mathrm{P}>0.05)$ between each treatments. This could be as a result of reduction in overall starch and gluten contents of the composite flour which is responsible for the gelling and viscoelastic properties to the flour. Roselle seed has high protein content and as such inclusion in the composite mix will only enrich the nutrient value of the flour. Gelatinization Maximum $[\mathrm{BU}]$ also decreased in all treatments with the inclusion of SDRSF; with $25 \%$ inclusion having the least values. However, in all the treatments the amylogram reveals that the samples meets the standard quality of bread rye, because all the gelatinization temperature was above $63^{\circ} \mathrm{C}$ and the gelatinization maximum was above 200 AU (AACC, 2000 Standard Method No. 22-10).

\section{Farinograph studies}

For decades the farinograph has been the standard instrument for measuring the water absorption, development time, stability, mixing tolerance index (MTI), time to break down and the farinograph quality number of the flour and whole meal, as well as testing the mixing and processing behavior of dough. These values extracted from the farinograph study can be used as a relative composite description of flour's overall quality characteristics. This has been used worldwide in accordance to international standard (AACC, 2000 Method No. 54-21). Farinograph results for composite flour of sprouted decorticated Roselle seed flour and wheat flour treatments are shown in Table 2. Based on the descriptive categories outlined by Preston (1984), the results obtained from farinograph studies outlined in Table 2 of the composite flour formulations can be categorized as follows: 
For sprouted decorticated Roselle seed flour (SDRSF), farinograph studies revealed that the range $10 \%-15 \%$ and $20 \%-25 \%$ composite flour can be categorized as strong and medium flours respectively (Preston, 1984), with $10 \%$ and $15 \%$ compared favourably with the control as strong flours. Having MTI values of 54.2, 66.7 and 31.75 BU; development time 7.5, 7.1 and $11.7 \mathrm{~min}$; and water absorption 82.13, 79.98 and $85.18 \%$ respectively (Table 2); there was a significant difference $(\mathrm{P}<0.05)$ between the observed values of dough characteristic of all the treatment formulations. Water absorption, development time, stability, and farinograph quality number (FQN) values decreased with inclusion of SDRSF in the composite mix, with the exception of MTI $[\mathrm{BU}]$ showing an inverse relationship.

For sprouted decorticated Roselle seed flour (SDRSF), farinogram classified the composite flour with $10 \%, 15 \%, 20 \%$, and $25 \%$ as strong, medium and weak flours respectively (Preston, 1984), with only $10 \%$ compared favourably with control as strong flours; having MTI values of 54.25 and $31.75 \mathrm{BU}$, development time 5.6 and $6.78 \mathrm{~min}$, and water absorption 76.33 and $79.58 \%$ respectively (Table 2).
There is a significant difference $(\mathrm{P}<0.05)$ between the observed values of dough characteristic of all the treatment formulations. Water absorption, development time, stability and farinograph quality number (FQN) values decreased with the inclusion of UDRSF in the composite mix, with the exception of MTI [BU] showing an inverse relationship.

For sprouted decorticated Roselle Seed Flour (SDRSF), the farinogram results categorized $10 \%-20 \%$ and $25 \%$ as strong and medium flour respectively (Preston, 1984), with $10 \%$, $15 \%$ and $20 \%$ compared favourably with Control as strong flours. Having MTI values of 42.0, 44.25, 45.0 and $31.75 \mathrm{BU}$, development time 5.60, 6.08, 5.65 and $6.78 \mathrm{~min}$, and water absorption $76.73,74.93,72.95$ and $79.58 \%$ respectively (Table 3 ). There is a significant difference $(\mathrm{P}<0.05)$ between the observed values of dough characteristic of all the treatment formulations. Water absorption, development time, stability, and farinograph quality number (FQN) values decreased with the inclusion of SWRSF in the composite mix, with the exception of MTI [BU] showing an inverse relationship.

Table.1 Effects of addition of sprouted decorticated Roselle seeds flour (SDRSF) on amylograph characteristic of dough

\begin{tabular}{|c|c|c|c|}
\hline $\begin{array}{l}\text { Treatments } \\
\text { Roselle seed flour:wheat }\end{array}$ & $\begin{array}{c}\text { Beginning of } \\
\text { gelatinization } \\
\left({ }^{0} \mathrm{C}\right)\end{array}$ & $\begin{array}{l}\text { Gelatinization } \\
\text { temperature }\left({ }^{0} \mathrm{C}\right)\end{array}$ & $\begin{array}{c}\text { Gelatinization } \\
\text { maximum (AU) }\end{array}$ \\
\hline Control (00:100) & 59.58 & 87.08 & 838.75 \\
\hline SDRSF 10:90 & 61.33 & 86.00 & 624.25 \\
\hline SDRSF 15:85 & 61.88 & 85.38 & 576.50 \\
\hline SDRSF 20:80 & 63.03 & 85.03 & 484.25 \\
\hline SDRSF 25:75 & 63.68 & 84.70 & 404.75 \\
\hline $\mathrm{SE}( \pm)$ & 0.05 & 0.13 & 0.61 \\
\hline CD $\operatorname{at5}(\%)$ & 0.14 & 0.40 & 1.83 \\
\hline CV (\%) & 0.15 & 0.31 & 0.21 \\
\hline
\end{tabular}

Each value is an average of four determinations. SDRSF $=$ Sprouted Decorticated Roselle Seed Flour. 
Table.2 Effects of addition of sprouted decorticated Roselle seeds flour (SDRSF) on farinograph characteristics of dough

\begin{tabular}{|c|c|c|c|c|c|c|c|c|c|}
\hline $\begin{array}{l}\text { Treatments } \\
\text { Roselle seed flour:wheat }\end{array}$ & $\begin{array}{c}\text { Consist } \\
\text { ency } \\
\text { [BU] }\end{array}$ & $\begin{array}{c}\text { Water } \\
\text { absor } \\
\text { ption } \\
\%\end{array}$ & $\begin{array}{c}\text { Water } \\
\text { absorption } \\
\text { (corrected } \\
\text { for } 500 \mathbf{B U})\end{array}$ & $\begin{array}{c}\text { Water } \\
\text { absorption } \\
\text { (corrected } \\
\text { for } 14 \%)\end{array}$ & $\begin{array}{l}\text { Dev. } \\
\text { time } \\
(\text { min })\end{array}$ & $\begin{array}{l}\text { Stability } \\
\text { (min) }\end{array}$ & $\begin{array}{l}\text { Mixing } \\
\text { Tolerance } \\
\text { Index } \\
\text { (BU) }\end{array}$ & $\begin{array}{c}\text { Time } \\
\text { of } \\
\text { break } \\
\text { down } \\
\text { (min) }\end{array}$ & $\begin{array}{c}\text { Farinograph } \\
\text { quality number } \\
\text { (FQN) }\end{array}$ \\
\hline Control (00:100) & 498.75 & 85.18 & 85.08 & 79.58 & 6.78 & 3.98 & 31.75 & 11.68 & 116.75 \\
\hline SDRSF 10:90 & 500.25 & 80.43 & 80.43 & 75.93 & 5.43 & 2.25 & 53.00 & 7.90 & 79.93 \\
\hline SDRSF 15:85 & 501.75 & 79.58 & 79.58 & 75.08 & 5.28 & 2.40 & 56.75 & 7.18 & 71.75 \\
\hline SDRSF 20:80 & 505.25 & 78.33 & 78.53 & 73.93 & 5.05 & 2.00 & 70.25 & 6.53 & 65.25 \\
\hline SDRSF 25:75 & 511.00 & 77.98 & 78.28 & 73.48 & 4.88 & 1.23 & 100.00 & 6.08 & 60.00 \\
\hline $\mathbf{S E}( \pm)$ & 0.53 & 0.05 & 0.05 & 0.04 & 0.05 & 0.04 & 0.41 & 0.05 & 0.41 \\
\hline CD at5 (\%) & 1.60 & 0.14 & 0.15 & 0.14 & 0.13 & 0.11 & 1.25 & 0.16 & 1.24 \\
\hline CV $(\%)$ & 0.21 & 0.12 & 0.12 & 0.13 & 1.63 & 3.18 & 1.32 & 1.35 & 1.05 \\
\hline
\end{tabular}

Each value is an average of four determinations. SDRSF = Sprouted Decorticated Roselle Seed Flour. 
Table.3 Effects of addition of sprouted decorticated Roselle seeds flour (SDRSF) on Energy $\left[\mathrm{cm}^{2}\right]$

\begin{tabular}{|l|c|c|c|}
\hline Treatments & \multicolumn{3}{|c|}{ Proving Time (min) } \\
\cline { 2 - 4 } Roselle seed flour:wheat & 30 & 60 & 90 \\
\hline Control (00:100) & 38.75 & 34.75 & 31.75 \\
\hline SDRSF 10:90 & 24.00 & 23.00 & 23.00 \\
\hline SDRSF 15:85 & 20.75 & 18.00 & 16.50 \\
\hline SDRSF 20:80 & 12.50 & 10.25 & 10.00 \\
\hline SDRSF 25:75 & 9.75 & 8.75 & 8.75 \\
\hline SE(土) & 0.47 & 0.45 & 0.42 \\
\hline CD at5 (\%) & 1.42 & 1.36 & 1.26 \\
\hline CV (\%) & 4.44 & 4.77 & 4.65 \\
\hline
\end{tabular}

Each value is an average of four determinations. SDRSF $=$ Sprouted Decorticated Roselle Seed Flour.

Table.4 Effects of addition of sprouted decorticated Roselle seeds flour (SDRSF) on Resistance to Extension [BU]

\begin{tabular}{|l|c|c|c|}
\hline \multirow{2}{*}{ Treatments } & \multicolumn{3}{|c|}{ Proving Time (min) } \\
\hline Roselle seed flour:wheat & 30 & 60 & 90 \\
\hline Control (00:100) & 304.75 & 263.75 & 251.75 \\
\hline SDRSF 10:90 & 170.00 & 167.00 & 170.00 \\
\hline SDRSF 15:85 & 141.00 & 129.25 & 127.00 \\
\hline SDRSF 20:80 & 90.50 & 79.00 & 72.75 \\
\hline SDRSF 25:75 & 60.75 & 49.75 & 45.75 \\
\hline SE(土) & 0.49 & 0.41 & 0.45 \\
\hline CD at5 (\%) & 1.48 & 1.24 & 1.36 \\
\hline CV (\%) & 0.64 & 0.60 & 0.68 \\
\hline
\end{tabular}

Each value is an average of four determinations. SDRSF $=$ Sprouted Decorticated Roselle Seed Flour.

Table.5 Effects of addition of sprouted decorticated Roselle seeds flour (SDRSF) on Extensibility [mm]

\begin{tabular}{|l|c|c|c|}
\hline Treatments & \multicolumn{3}{|c|}{ Proving Time (min) } \\
\hline Roselle seed flour:wheat & 30 & 60 & 90 \\
\hline Control (00:100) & 88.75 & 89.75 & 81.75 \\
\hline SDRSF 10:90 & 93.25 & 88.25 & 79.00 \\
\hline SDRSF 15:85 & 92.75 & 87.00 & 77.75 \\
\hline SDRSF 20:80 & 84.25 & 70.25 & 61.00 \\
\hline SDRSF 25:75 & 71.25 & 61.00 & 59.75 \\
\hline SE(土) & 0.48 & 0.64 & 0.45 \\
\hline CD at5 (\%) & 1.44 & 1.92 & 1.36 \\
\hline CV (\%) & 1.11 & 1.60 & 1.26 \\
\hline
\end{tabular}

Each value is an average of four determinations. SDRSF $=$ Sprouted Decorticated Roselle Seed Flour. 
Table.6 Effects of addition of sprouted decorticated Roselle seeds flour (SDRSF) on Maximum [BU]

\begin{tabular}{|l|c|c|c|}
\hline Treatments & \multicolumn{3}{|c|}{ Proving Time (min) } \\
\hline Roselle seed flour:wheat & 30 & 60 & 90 \\
\hline Control (00:100) & 317.75 & 277.75 & 270.75 \\
\hline SDRSF 10:90 & 184.00 & 189.00 & 185.25 \\
\hline SDRSF 15:85 & 163.00 & 148.25 & 151.75 \\
\hline SDRSF 20:80 & 123.75 & 124.00 & 129.25 \\
\hline SDRSF 25:75 & 107.75 & 109.75 & 115.75 \\
\hline SE(土) & 0.45 & 0.49 & 0.47 \\
\hline CD at5 (\%) & 1.36 & 1.47 & 1.44 \\
\hline CV (\%) & 0.50 & 0.57 & 0.56 \\
\hline
\end{tabular}

Each value is an average of four determinations. SDRSF $=$ Sprouted Decorticated Roselle Seed Flour.

Table.7 Effects of addition of sprouted decorticated Roselle seeds flour (SDRSF) on Ratio Number

\begin{tabular}{|l|c|c|c|}
\hline Treatments & \multicolumn{3}{|c|}{ Proving Time (min) } \\
\cline { 2 - 4 } Roselle seed flour:wheat & 30 & 60 & 90 \\
\hline Control (00:100) & 3.58 & 3.08 & 3.18 \\
\hline SDRSF 10:90 & 1.78 & 1.83 & 2.00 \\
\hline SDRSF 15:85 & 1.58 & 1.58 & 1.68 \\
\hline SDRSF 20:80 & 1.10 & 1.03 & 1.13 \\
\hline SDRSF 25:75 & 0.88 & 0.88 & 0.88 \\
\hline SE( $\mathbf{( )}$ & 0.05 & 0.04 & 0.05 \\
\hline CD at5 (\%) & 0.15 & 0.14 & 0.14 \\
\hline CV (\%) & 5.62 & 5.72 & 5.26 \\
\hline
\end{tabular}

Each value is an average of four determinations. SDRSF $=$ Sprouted Decorticated Roselle Seed Flour.

Table.8 Effects of addition of sprouted decorticated Roselle seeds flour (SDRSF) on Ratio Number [Max]

\begin{tabular}{|l|c|c|c|}
\hline Treatments & \multicolumn{3}{|c|}{ Proving Time (min) } \\
\hline Roselle seed flour:wheat & 30 & 60 & 90 \\
\hline Control (00:100) & 3.68 & 3.18 & 3.38 \\
\hline SDRSF 10:90 & 1.93 & 2.03 & 2.13 \\
\hline SDRSF 15:85 & 1.88 & 1.85 & 2.08 \\
\hline SDRSF 20:80 & 1.53 & 1.70 & 1.83 \\
\hline SDRSF 25:75 & 1.48 & 1.58 & 1.70 \\
\hline SE( $\mathbf{( )}$ & 0.05 & 0.04 & 0.05 \\
\hline CD at5 (\%) & 0.14 & 0.13 & 0.14 \\
\hline CV (\%) & 4.57 & 4.19 & 4.18 \\
\hline
\end{tabular}

Each value is an average of four determinations. SDRSF $=$ Sprouted Decorticated Roselle Seed Flour. 
For Sprouted Decorticated Roselle Seed Flour (SDRSF), the farinogram defined and categorized $10 \%, 15 \%-20 \%$, and $25 \%$ as strong, medium and weak flours respectively (Preston, 1984), with 10\% compared favourably with Control as strong flours. Having MTI values of 53.0 and $31.75 \mathrm{BU}$, development time 5.43 and $6.78 \mathrm{~min}$, and water absorption 75.93 and $79.58 \%$ respectively see Table 4 . There is a significance difference $(\mathrm{P}<0.05)$ between the observed values of dough characteristic of all the treatment formulations. Water absorption, Development time, stability, and farinograph quality number $(\mathrm{FQN})$ values decreased with the inclusion of SDRSF in the composite mix, with the exception of MTI [BU] showing an inverse relationship (El-Adawy and Khalil, 1994; Ismail et al., 2008). This study provides sufficient results on water absorption and dough development properties of Roselle seeds flour in composite formulation with wheat; results may serve as a guide to bakers in its utilization as an enriched ingredient in value added bakery products

\section{Extensograph studies}

The extensograph technique was used to study the rheological properties of the mix flour of Roselle seed flour and wheat flour used for the preparation of various bakery products. Under this study energy required, resistance to extension, extensibility, maximum [BU], ratio number and ratio number [Max] index parameters were studied. Results for wheat flour (control), sprouted decorticated Roselle seed flour are presented in Tables 4-8. The results of extensograph indicated that decorticated without sprouting and after sprouting Roselle seed flour gave good results for better quality of the bakery products such as cookies. However, the decorticated flour sample showed slightly lower values than the whole seed flour for all above extensograph observations. There is no any literature on these aspects for supporting these results.

\section{References}

AACC. (2000). Amylograph, Farinograph and Extensograph, Approved methods of the American Association of Cereal Chemists (10th ed.). St. Paul, MN: Author (methods No. 22-10, 54-21 and 54-10

Bala, A., Gul, K. and Riar, C. S. (2015). Functional and sensory properties of cookies prepared from wheat flour supplemented with cassava and water chestnut flours. Cogent Food \& Agriculture, 1, 1019815.

Bambgoye, A.I. and Adejumo, O.I. (2009). Physical Properties of Roselle (Hibiscus $\begin{array}{llll}\text { sabdariffa } \quad \text { L.) Seed. Agricultural } & \text { Sell }\end{array}$ Engineering International: the CIGR Ejournal. Manuscript 1154.Vol. XI.

El-Adawy, T.A. and Khalil, A.H. (1994). Characteristics of roselle seeds as a new source of protein and lipid. Journal of Agricultural and Food Chemistry 42, 18961900

Emmy Hainida, K.I., Amin, I., Normah, H., Norhaizan, M.E., and Ainul, Z. (2008). Effects of defatted dried roselle (Hibiscus sabdariffa $L$.) Seed powder on lipid profiles of hypercholesterolemia rats. J. Sci. Food Agric. 88: 1043-1050.

Ismail, A., Emmy Hainida, K.I. and Halimatul, S.M.N. (2008). Roselle (Hibiscus sabdariffa L.) seeds-Nutritional Composition, Protein Quality and Health Benefits, Food 2(1), 1-16.

Karma Bako Rimamcwe, U. D. Chavan and P. M. Kotecha (2020). Rheological Properties of Roselle Seed Flour. Int. J. Curr. Microbiol. App. Sci. 9(7): 1856-1876.

Karma Bako Rimamcwe, Chavan, U. D., Lande, S. B. and Kotecha, P. M. (2019). Effects of addition of decorticated Roselle seeds flour on rheological properties. International Journal of Current Research. 11 (03): 23742378.

Karma Bako Rimamcwe and U.D. Chavan (2017d). Antioxidant Activity and Nutritional Value of Roselle Seeds Flour. 
Int. J. Curr. Microbiol. App. Sci. 6(4): 2654-2663.

Karma Bako Rimamcwe, Chavan, U. D., Dalvi, U. S. and Gaikwad, R. S. (2017c). Nutritional quality of Roselle seed flour cookies. International Journal of Current Research. 9: (12): 63053-63058.

Karma Bako Rimamcwe, Chavan, U. D., Nimbalkar, C. A. and Kahar, S. P. (2017a). Rheometry of Roselle (Hibiscus Sabdariffa L.) seed oil. Int. J. Pure App. Biosci. 5 (2): 987-993.

Karma Bako Rimamcwe, Chavan, U. D., Pawar, G. H. and Gaikwad, R. S. (2017b). Nitrogen Solubility and Functional Properties of Roselle Seed Flour. Int. J. Curr. Microbiol. App. Sci. 6(8): 1131-1139.

Karma Bako Rimamcwe, U. D. Chavan, S. B. Lande, C. A. Nimbalkar and U. S. Dalvi. (2018a). Physical and sensory quality of Roselle seed flour cookies. Int. J. Adv. Res. Biol. Sci. 5: (5): 160-171.

Karma Bako Rimamcwe, U.D. Chavan, Ashok Kadlag and V.S. Wani. (2018b). Effect of Addition of Roselle Seed Flour on Color and Textural Properties of Cookies. Int. J. Curr. Microbiol. App. Sci. 7 (4): 37263737.

Karma Bako Rimamcwe., Chavan, U. D., Kadlag, A. D., Todmal, S. M. and Wani, V. S. (2018c). Effect of addition of whole Roselle seed flour on rheological properties of whole wheat flour. International Journal of Current Research. 10 (6): 70848-70856.

Karma, B.R. and Chavan, U.D. (2016). Physical Properties and Nutritional Potentials of Indian Roselle (Hibiscus sabdariffa L.) Seeds. Int. J. of Cur. Res., 8(9): 3864438648.

Myfolia.com (2016), online source: https://myfolia.com

Nyam KL, Tan YN, Tan CP and Kamariah, L., (2012). In vitro Antioxidant Activities of
Extract and Oil from Roselle (Hibiscus sabdariffa L.) Seed against Sunflower Oil Autoxidation, Mal J Nutri 18(2): 265-274.

Nyam, Kar-Lin; Leao, Sod-Ying; Tan, Chin-Ping; and Long, Kamariah (2014). Functional Properties of Roselle (Hibiscus sabdariffa L.) seed and its application as bakery product, J. Food Sci. Technol 51(12):38303837.

Nzikou, J.M., Bouanga-Kalou, G., Latos, L., Ganongo-Po, F.B., Mboungou-Mboussi, P.S., Moutoula, F.E., Panyoo-Akdowa, E., Silou, T.H., and Desobry, S. (2012). Characteristics and Nutritional Evaluation of Seed oil from Roselle (Hibiscus sabdariffa L.) in Congo-Brazzaville, Current Research Journal of Biological Sciences 3(2): 141-146.

Panse, V.G. and Sukhatme, P.V. (1967). Statistical methods for Agricultural Workers. $4^{\text {th }}$ edn., New Delhi

Platon, JF. (1997). Lipids in Cosmetology. Ol. Corps Gras Lipid; 4: 275-281.

Preston, K.R. (1984). Use of lyotropic salts to study the hydrophobic properties of wheat gluten proteins. Proc. Intl. Workshop on Gluten Proteins, $2^{\text {nd }}$, TNO, Wageningen.

Ramadan M.F. and Morsel J.T. (2004). Oxidative stability of black cumin (Nigella sativa L.), coriander (Coriandrum sativum L.) and niger (Guizotia abyssinica Cass.) crude seeAd oils upon stripping. Eur J Lipid Sci Technol; 106: 35-43.

Wani, S. H., Gull, A., Allaie, F., and Safapuri, T. A. (2015). Effects of incorporation of whey protein concentrate on physicochemical, texture, and microbial evaluation of developed cookies. Cogent Food \& Agriculture, 1, 1092406.

Yayock, J.Y., Lombin, G. and Owonubi, J.J. (1988) Crop Science and Production in Warm Climates. Macmillan Publishers, London, p.307.

\section{How to cite this article:}

Karma Bako Rimamcwe, U. D. Chavan and Kotecha, P. M. 2020. Effects of Addition of Sprouted Decorticated Roselle Seeds Flour on Rheological Properties. Int.J.Curr.Microbiol.App.Sci. 9(10): 2316-2326. doi: https://doi.org/10.20546/ijcmas.2020.910.279 